\title{
Impact of Soil Fauna on the Properties of Soils in the Humid Tropics $^{1}$
}

\author{
P. Lavelle, E. Blanchart, and A. Martin \\ Ecole Normale Supèrieure \\ Paris, France
}

A. V. Spain

1107 Ross River Road

Rasmussen, Queensland, Australia

\section{S. Martin}

Chargé de Mission au Ministère de l'Environnement Neuilly-sur-Seine, France

The sustainability of soil fertility in agricultural systems of the humid tropics has recently become a major issue as a consequence of continued land degradation and the critical need to provide more food (FAO, 1981; Swaminathan, 1983). For socioeconomic, pedological, and ecological reasons, the development of sustainable high-input agriculture has proven to be slow and difficult and much effort needs to be directed towards the improvement of productivity in low-input agriculture.

In traditional low-input systems, sustainability is not achieved. Crop yields decrease rapidly following clearing and the land is generally abandoned after a few crops, providing a constant pressure to clear new land (e.g., Ayodele, 1986; Sanchez et al., 1983). Decreases in soil fertility are due not only to nutrient loss exported as crops (e.g., Sanchez et al., 1989). Other factors accelerating fertility losses include:

1. The erosion of exposed soil leading to the loss of the fine particles rich in organic matter and nutrients.

2. Overmineralization of soil organic matter (SOM) and plant residues due to the overheating of bare soil.

\footnotetext{
'Contribution from Laboratoire d'Ecologie de l'Ecole Normale Superieure de Paris (UA CNRS no. 258). The authors express appreciation to Ministere de l'Environnement (SRETIE, Relations Internationales) for financial assistance.
}

Copyright (C) 1992 Soil Science Society of America and American Society of Agronomy, 677 S. Segoe Rd., Madison, WI 53711, USA. Myths and Science of Soils of the Tropics. SSSA Special Publication no. 29. 
3. Nutrient leaching by high water fluxes and a lack of synchrony between nutrient release and plant demand.

4. Deterioration of soil structure consequent on the decreased activity of soil macroorganisms (macrofauna and roots).

The situation in adjacent natural systems provides a marked contrast. Primary productivity levels of several tens of megagrams of dry mass ha ${ }^{-1}$ are generally sustained, even in apparently poor infertile soils (e.g., Herrera et al., 1978; Bernhardt-Reversat et al., 1979) and the differences are not readily explained solely by the export of crops from the exploited systems. Nearly closed nutrient cycles ensure an optimal conservation of mineral fertility whereas soil structure is maintained through diverse processes, particularly intense biological activity. It is, therefore, critical to understand the nature and relative importance of the biological processes that maintain fertility, to use them in cropping systems and thus improve the sustainability of their use (Swift, 1984).

This chapter first discusses the relative importance of biological processes, particularly those mediated by the soil fauna, on the maintenance of fertility in the soils of the humid tropics. Because of the relatively recent recognition of the soil fauna as constituting a major controlling influence on the productivity of tropical ecosystems, only two important myths have emerged. The first of these suggests that the earthworm (Lumbricidae) is important in the soils of the temperate areas while the termite is the dominant animal of the tropics. The second states that the earthworm is the product rather than the cause of high fertility. In refuting these myths, the composition of macroinvertebrate communities and the relative importance of their components in the major ecosystems of the humid tropics are considered. Finally, the effects of the two dominant macrofaunal groups, the earthworm and the termite on SOM dynamics and soil structure are detailed.

In this chapter, we confine discussion largely to the saprophagous organisms that process dead plant materials and SOM or exert a major influence on the soil processes that guide the functioning of its systems and evolution. We, therefore, largely omit discussion of the ant despite their undoubted influence on soil communities since most operate at the higher trophic levels in nature. It is only the leaf-cutter ant (tribe Attini) that derive most of its energy from cellulose and then act as active herbivores.

\section{BIOLOGICAL SYSTEMS OF REGULATION AND SOIL FERTILITY}

Soil fertility has two major components:

1. Nutrient supply to plants which in turn depends on: (i) the intensity and spatial and temporal pattern of nutrient release through the mineralization of decomposing organic matter and (ii) the ability of soil to retain a store of cations in exchangeable form on the surfaces of colloids (clay minerals and SOM). Decomposition is thus shown to be a key process for soil fertility through its effects on both mineralization and humification. 
2. Soil physical structure, which controls the void space and thus the amounts of water and oxygen stored in the soil and the rate of their supply to roots. Decomposition and physical structure are both determined by a suite of hierarchically organized factors that operate at different temporal and spatial scales (Anderson et al., 1989; Lavelle et al., 1991) (Fig. 9-1). At the highest level of the hierarchy, the climate (i.e., precipitation and temperature regimes) generally accounts for much of the large-scale variation in decomposition rates and parent material weathering (Heal et al., 1981; Pedro, 1983).

At the next level down, parent material characteristics strongly influence soil texture, nutrient status, and both the abundance and nature of the clay minerals. They thus determine both decomposition rates and soil physical structure. At an even lower level, the quality of organic inputs greatly affects decomposition rates through the different ways in which chemicals inhibit microbial activity (e.g., the inhibition of $\mathrm{N}$ release from resistant phenol-protein complexes and situations where the $\mathrm{C} /$ nutrient ratios are imbalanced or lignin contents are high).

Finally, at the lowest level of resolution, integrated groups of organisms formed into biological systems of regulation (Lavelle, 1984) directly mediate decomposition through their digestive activities and the production of metabolites, feces, and casts with distinctive physical and chemical properties. Biological systems of regulation are composed of macroorganisms (in-

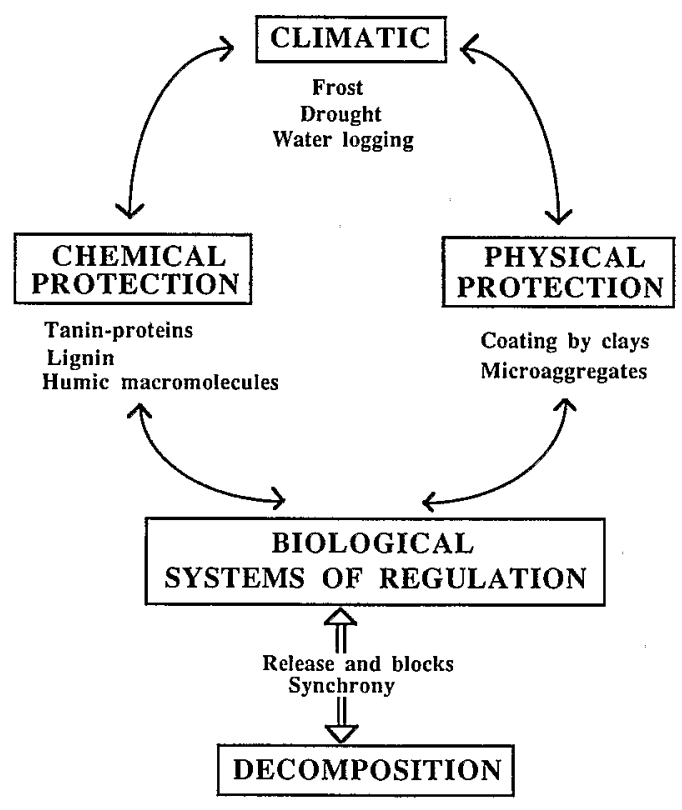

Fig. 9-1. Hierarchy of factors that determine microbial activity and eventually decomposition rates. 


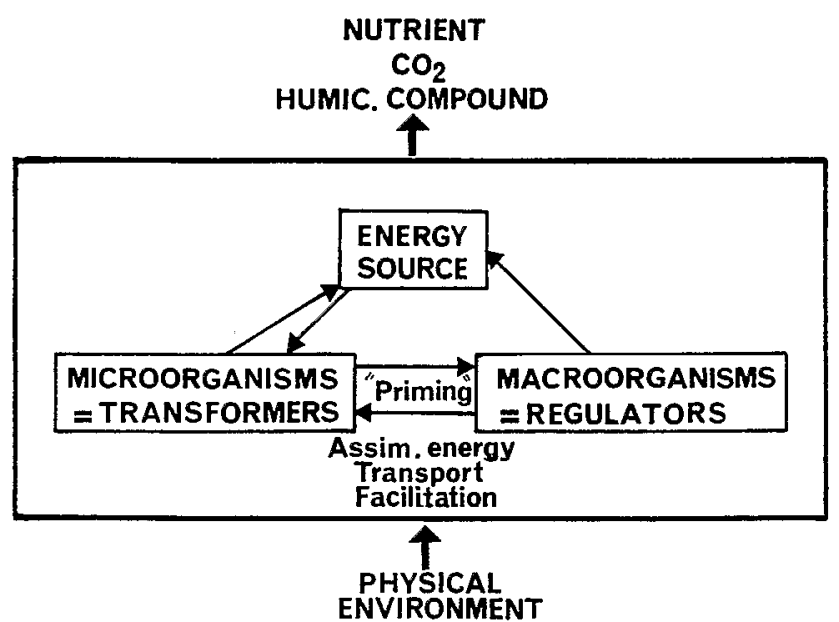

Fig. 9-2. General organization of biological systems of regulations in soils (Lavelle, 1984).

vertebrates and roots) and microorganisms (mainly fungi and bacteria) whose activity is directly controlled by that of the macroorganisms (Fig. 9-2).

Microbial communities are able to effect almost any kind of chemical transformation, and certainly may even change their individual metabolic functions in response to altered environmental conditions (e.g., Swift, 1976; Visser, 1985). However, microorganisms have extremely limited capacities for movement and may thus remain for long periods in inactive resting stages because they are physically separated from their food resources or lack suitable microenvironment conditions. This is especially true of bacteria, whereas fungi are relatively more mobile and less dependent on specific, localized environmental conditions.

Calculated turnover times for microbial biomass give unexpectedly high estimates of about 1 to $2 \mathrm{yr}$ in temperate soils, and more than $0.5 \mathrm{yr}$ in tropical soils (Jenkinson \& Ladd, 1981; Chaussod et al., 1986) while generation times may be $<20 \mathrm{~h}$ under optimum laboratory conditions (Clarholm \& Rosswall, 1981). Much of the microbial population thus spends a large proportion of the time in dormant stages with low metabolic activity awaiting favorable conditions. During this period, their size progressively diminishes to the point beyond which reactivation is no longer possible.

Reactivation of dormant microorganisms and propagules normally results from the activity of macroorganisms that brings them into contact with new nutritional substrates (by mixing the soil or moving into it) and provides them with water and readily assimilable organic matter (in the form of root exudates or earthworm cutaneous and intestinal mucus). Microorganisms initially utilize these resources to reach the high metabolic levels at which they are able to use more complex organic substrates (Barois \& Lavelle, 1986; Coleman et al., 1983). Such "priming effects" (Jenkinson, 1966) have been measured in the rhizosphere in response to exudate production (Billes et al., 1986) and in the gut of the endogeic earthworm (drilosphere) as a 


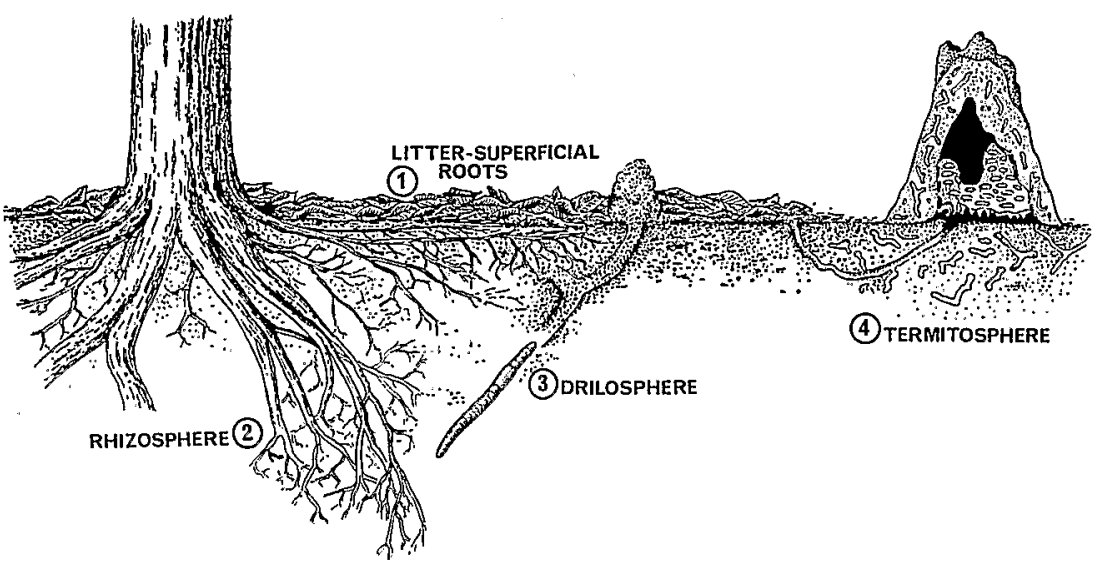

Fig. 9-3. The four principal biological systems of regulation. (After Lavelle, 1984.)

response to intestinal mucus (Barois \& Lavelle, 1986; Martin et al., 1987). Similar effects may be triggered in the guts and galleries of termites (termitosphere) and the litter system when water-soluble organic matter leached by rain contacts the dormant microorganisms of the subsoil.

There are four principal biological systems of regulation (Fig. 9-3).

1. The first system is the litter-superficial roots system, the main function of which is a direct cycling of nutrients from the leaf litter to surface roots, thus preventing losses. In that system, litter is the energy source. The microflora is dominated by fungi and macroorganisms that comprise a rich and diverse community of litter-feeding arthropods and Oligochaetes (epigeic earthworms and Enchytraeidae). Surface roots growing among the decomposing leaves act as a sink for the nutrients released.

2. The second system is the rhizosphere. It is a focus for the active mutualistic interactions between roots, microflora, and an associate microfauna (Protozoa and Nematodes). The system is activated by the production of root exudates.

3. The third is the drilosphere, which comprises the geophagous earthworm populations and the soil that they influence (i.e., intestinal contents, castings, and galleries).

4. The fourth is the termitosphere, which is defined as termites and the whole soil and microflora that they influence through their activities. Microbial communities are diverse and occasionally highly specific (e.g., gut symbionts and Termitomyces spp. that are the characteristic fungi cultivated in the fungus gardens of macrotermitine termites).

In the soils of the humid tropics, the critical level in the hierarchy of the factors determining soil fertility is variable. Climatic controls become ineffective when temperatures are constantly elevated and moisture limits activity for only short periods. The effect of clay minerals (kaolinite and oxy- 
hydroxides) as regulators of decomposition and the basis of the soil structure is limited in many soils due to their frequently low reactivities and occasional low abundance. Consequently, decomposition and fertility processes are likely to be regulated at the lowest level (i.e., that of resource quality and biological systems of regulation). Thus, soil invertebrates are likely to be the major regulators of decomposition in many tropical situations. This is particularly true of macroinvertebrates whose effects on soil microorganisms may be dramatic due to the relatively large scales of space and time at which they operate. Macroinvertebrates also have major effects on soil structure by forming macropores, digging galleries, and egesting the casts and pellets that are often the basic components of well-developed macroaggregate structures.

\section{SOIL MACROINVERTEBRATE COMMUNITIES IN THE HUMID TROPICS}

\section{Classification of Soil Invertebrates}

Soil organisms face three major constraints. They feed on relatively lowquality resources, move in a compact and amphibious environment, and must be preadapted to survive occasionally unfavorable temperature and moisture conditions.

Three main strategies have been developed to cope with these constraints.

1. Microbionts (i.e., microorganisms and the microfauna) are small $(<0.2 \mathrm{~mm})$ and live in water-filled pores. Microorganisms have a considerable ability to digest low-quality substrates and may survive unfavorable temperature and moisture conditions by sheltering in soil micropores. Nonetheless, they have a limited capacity to move and no access to the physically protected organic matter present within soil microaggregates. The most important groups of microfauna are the Nematoda and Protozoa.

2. Macrofauna $(>1 \mathrm{~cm})$ form a marked contrast in that their enzymatic capacities are generally limited and they have little ability to withstand harsh environmental conditions. However, they can move through the soil by digging galleries and burrows. They break the physical protection of soil organic matter during the process of ingesting and mixing the soil in their gut. One part of the macrofauna does not enter the soil but remains in the leaf litter since it possesses no adaptations for digging. This section includes a range of large insects (Coleoptera and Diptera larvae) and other Arthropoda (e.g., Isopoda, Myriapoda, and Arachnida). The main soil-dwelling components of the macrofauna are the earthworm, termite, and ant, some of which may also live in the litter and feed on it.

3. The mesofauna $(0.2-1.0 \mathrm{~mm})$ has an intermediate strategy in that the members of this group move through existing soil cracks and natural channels, but are unable to move through the undisturbed soil. They are usually confined to the surface litter and have a well-developed resistance to drought and extreme temperatures. This group comprises microarthropods (i.e., Col- 
lembola, Acari, and several other groups) and small whitish worms of the Oligochaete family Enchytraeidae.

Only the macrofauna will be considered here as the abundance of smaller animals and their effects on fertility are still poorly documented and appear to operate at very small scales. Their activities appear, in some cases, to be controlled by those of higher organisms (e.g., nematodes and protozoa in the micro-food chain of the rhizosphere, or Collembola and Acari in litter systems dominated by the activities of the larger arthropod or earthworm).

The macrofauna, in its turn, may be divided into three main functional groups, depending on the kind of food they use (surface litter or underground litter or SOM) and their location in the profile (litter, subsoil, or burrows and nests):

1. Epigeics live in the litter; they feed on decomposing litter, live microorganisms (mainly fungi), or invertebrates. They have no effect on the soil structure as they are unable to dig the soil. Their main effect is the fragmentation, comminution, and partial digestion of litter. They comprise a very diverse community of saprophagous and predator arthropods (e.g., microarthropods, myriapods, isopods, and arachnids), some pigmented earthworms and a few other groups of invertebrates (e.g., gastropods);

2. Encogeics live in the soil. They mainly feed on soil organic matter and dead roots. Live roots seem to be a poor resource as they are seldom consumed by endogeics (see e.g., Lavelle, 1983; Lavelle et al., 1989b). Endogeics have been divided into oligo-, meso-, and polyhumics according to how they ingest: (i) soil of the deep horizons with a low organic content; (ii) the bulk soil of the upper 10 to $25 \mathrm{~cm}$; and (iii) soil of the upper horizon enriched in organic matter by preferentially feeding in organic-rich pockets of soil (e.g., rhizosphere) or ingesting fine particles with a high organic content rather than coarse sand particles. Endogeics are active diggers that may greatly enhance soil aggregation. They mainly comprise earthworms, humivorous termites, and a few rhizophage arthropods.

3. Anecics feed in the litter but live in the soil in subterranean nests or galleries, or in epigeic nests. Their main effect is to export litter from the litter system to other systems in which the time course and pathways of decomposition are different. They also affect soil physical characteristics (e.g., water infiltration and aeration by digging galleries). This category includes the largepigmented earthworm and a large proportion of termite.

\section{Macrofauna Communities}

In the humid tropics, the nature of the diverse macroinvertebrate communities depends largely on vegetation type (Fig. 9-4). Forests generally have highly diverse communities in which the epigeic litter arthropod and anecic termite are dominant in population density terms, although endogeic and anecic earthworms may be major components of biomass. In the more humid savannas and pastures, the endogeic earthworm is always a dominant component of biomass. In natural savannas, however, the termite is frequent- 
a

GRASSLAND

SHRUB SAVANNA Lamto (Ivory Coast)

PASTURE

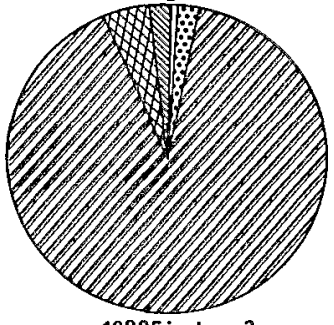

10905 ind. $\mathrm{m}^{-2}$

Laguna Verde(Mexico)

1830

ind. $m-2$

[5:07) Earthworms

WID Termites

EXXX Ants

Mint Coleoptera

$\square$ Myriapoda

Arachnid

FOREST

PRIMARY FOREST

PRIMARY FOREST

Bonampak(Mexico)

Yurimaguas (Peru)
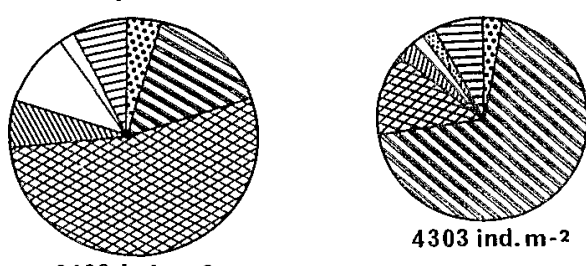

6409 ind. $m-2$

\section{DENSITY}

b

GRASSLAND

SHRUB SAVANNA

Lamto(lvory Coast)

PASTURE

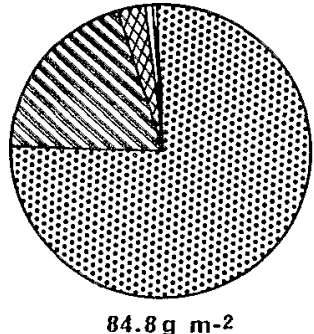

Laguna Verde(Mexico)

$84.8 \mathrm{~g} \mathrm{m-2}$

FOREST

PRIMARY FOREST

Yurimaguas (Peru)

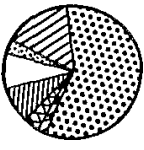

$18.9 \mathrm{~g} \mathrm{~m}-2$

Earthworms
Termites
Ants
Coleoptera
$\square$ Myriapoda
Arachnida
Others

\section{BIOMASS}

Fig. 9-4. Density (a) and biomass (b) structure of macrofauna communities in grasslands and forests of the humid tropics (Lavelle et al., 1981; Lavelle, 1983; Lavelle \& Kohlmann, 1984; Lavelle \& Pashanasi, 1989). 
ly dominant or important and significant populations of ants or litter or rootfeeding arthropods may be present.

The termite (Isoptera) is a group of social exopterygote insects allied to the cockroach (Blattodea). Species diversity decreases markedly from the lower to the higher latitudes of $45^{\circ} \mathrm{N}$ and $45^{\circ} \mathrm{S}$. Species diversity also decreases sharply with increasing elevation (Wood, 1979, 1988; Collins, 1983).

The occurence of the termite and distribution of its feeding habits depends mostly on biogeographic factors and climatic patterns. In America, fungus-cultivating termites (Termitidae and Macrotermitidae) are not represented and termite abundance is generally limited as compared to equivalent climatic areas of Africa and Australia. Australia, while not possessing the fungus-cultivating termite, has a rich and diverse termite fauna.

Earthworm communities also exhibit similar large-scale variations. This is especially true in forests where geographic variation is noticeable. It has been found, however, that beyond biogeographical differences the abundance and distribution of populations into ecological categories are ultimately determined by rain. "Dry" forests have relatively low populations, dominated by epigeic species while, in moderately wet areas (1800-2500 $\mathrm{mm}$ of annual rainfall) endogeic species often predominate and biomass is at a maximum. In wetter areas, where high leaching has impoverished the soils, earthworm biomass tends to be lower and endogeics are partly replaced by anecic and epigeic populations. Finally, in areas receiving more than 4000 to $5000 \mathrm{~mm}$ annually, earthworm populations are generally small (Fragoso \& Lavelle, 1990).

The earthworm and termite are by far the most active components of the soil fauna with respect to their influences on soil structure and SOM dynamics. The earthworm is especially active in the upper 10 to $20 \mathrm{~cm}$ of soil and, when abundant, may exert a day-to-day regulation of microbial activity with immediate as well as medium-term effects (months to years). The termite is active throughout and even below the profile and their effects on soil structure and SOM dynamics are manifested partly on a short-term basis and partly in the long term (years to decades). Another major difference between the termite and earthworm is that the activities of the latter are rather uniformly distributed on a horizontal dimension whereas termite activities are concentrated in their nests and galleries.

\section{EARTHWORM EFFECTS: THE DRILOSPHERE SYSTEM}

The earthworm communities of the humid tropics are largely dominated by endogeic populations that use SOM as a nutritional resource. As a result, the overall effects of earthworm communities on soils differ substantially between the humid tropics and the temperate areas that are dominated by epigeic and anecic populations feeding on leaf litter (Lavelle, 1983). This section examines the effects of the endogeic earthworm on the soil physical structure and SOM dynamics in the humid tropics. 


\section{Effect of the Earthworm on Soil Physical Structure}

\section{Drilosphere Structures}

The endogeic earthworm has a major effect on soil structure by promoting macroaggregation (i.e., the combination of soil particles into stable compound structures). Its effect on water infiltration and the vertical mixing of soil horizons may also be significant, even though it does not build burrow systems and only leaves evenly distributed macropores in the soil it colonizes.

Individuals may ingest daily from 5 to 30 times their own weight of soil, depending on the species and soil conditions (Lavelle, 1975, 1988). As a result, field populations with biomasses of 200 to $1000 \mathrm{~kg}$ fresh wt ha ${ }^{-1}$ may annually ingest from a few hundred to $1250 \mathrm{Mg}$ of dry soil ha ${ }^{-1}$ (Lavelle, 1978). Most of this soil is egested into the subsoil. Only a small proportion is egested at the soil surface as casts. Two main kinds of casts may be distinguished, that is: (i) globular casts of high stability, comprised of coalescent round or flattened subunits and (ii) granular casts comprised of an accumulation of small, fragile, fine-textured pellets, with little structural stability.

An annual production of surface casts of 14 to $15 \mathrm{Mg} \mathrm{ha}^{-1}$ has been measured in tropical Costa Rican pastures colonized by high populations of the pantropical endogeic earthworm Pontoscolex corethrurus (Fraile, 1989). Even high figures of 25 to $30 \mathrm{Mg} \mathrm{ha}^{-1}$ have been recorded from the moist savannas of the Ivory Coast and the Cameroons (Kollmannsperger, 1956; Lavelle, 1978). However, at Lamto this only represents 1.7 to $3.5 \%$ of the 800 to $1250 \mathrm{Mg}$ of dry soil that the endogeic earthworm ingests annually. Interestingly, this proportion varies seasonally probably as a response to soil compaction, and is maximum when the overall soil ingestion is minimum (Fig. 9-5).

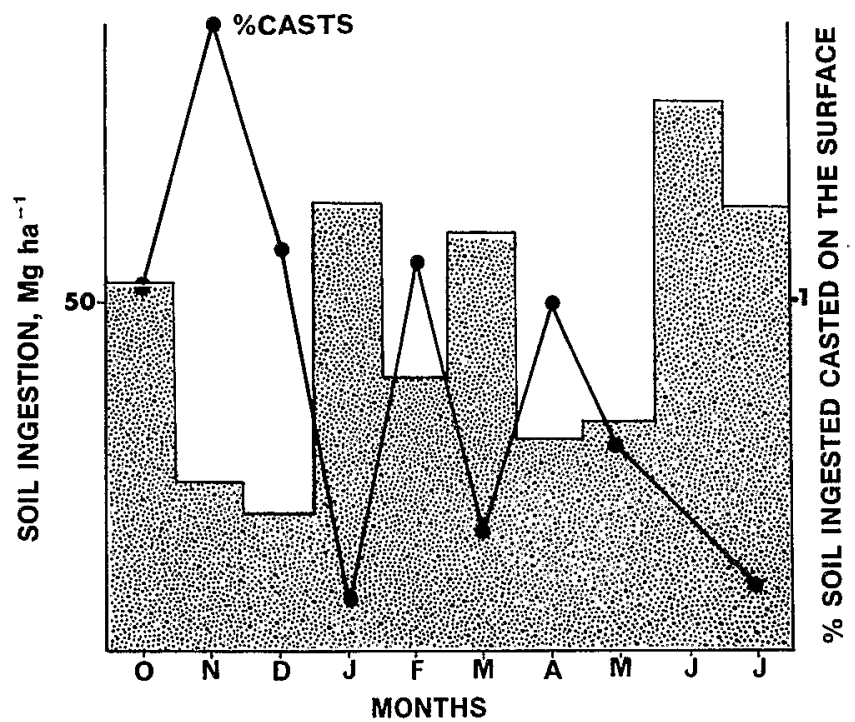

Fig. 9-5. Seasonal variations of soil ingestion (blocks) and surface cast (solid line) production by earthworm at Lamto (Ivory Coast). (After Lavelle, 1978.) 


\section{Soil Aggregation}

In humid tropical soils with high endogeic earthworm activity, casts deposited in the subsoil are the component units of stable macroaggregate structures. Such macroaggregates may comprise 50 to $60 \%$ of the soil (Blanchart, 1990) (Fig. 9-6). Experiments conducted on savanna soils at Lamto (Ivory Coast) have demonstrated that macroaggregate structures may form in the presence of the endogeic earthworm in surprisingly short periods. In $33 \mathrm{~d}$, the activity of $5 \mathrm{~g}$ fresh weight of Millsonia anomala in $6800 \mathrm{~g}$ of soil resulted in the formation of $2883 \mathrm{~g}$ of aggregates (i.e., $42.4 \%$ of the soil in the experimental container), as compared to $1075 \mathrm{~g}(15.8 \%)$ in a treatment with the perennial grass Panicum maximum Jacq. and $906 \mathrm{~g} \mathrm{(13.3 \% )}$ in a control treatment with neither plants nor earthworm (Blanchart et al., 1990). In such a short period, only $1815 \mathrm{~g}(26.7 \%)$ of aggregates might have been produced as earthworm casts according to earlier results (Lavelle, 1975). This indicates that factors other than the simple production of globular casts contribute to aggregation. The difference (i.e., 15.7\%) might be due to the proliferation of fungal hyphae that may have linked together soil particles (Tisdall \& Oades, 1982).

When the earthworm is excluded from a soil within which they had formed a macroaggregate structure, this structure remains stable for a long time (at least several years) due to the stabilization of aggregates with time. Alternation of dry and wet periods seems to particularly favor this aggregate stabilization. The introduction of the earthworm producing small granular casts, however, leads to the progressive destruction of the structure as large aggregates are split into much smaller and more fragile ones (Fig. 9-7). It is hypothesized that, in natural ecosystems such as the savannas at Lamto (Ivory Coast), excessive soil aggregation that may negatively affect plant growth (e.g., Rose \& Wood, 1980; Spain et al., 1990) is prevented by the activities of the small earthworm that maintain soil macroaggregation at less than a maximum value of approximately $60 \%$ of the soil as macroaggregates larger than $2 \mathrm{~mm}$ (Blanchart, 1990).

\section{Water Infiltration}

The earthworm may also greatly affect water infiltration. In West African soils, Casenave and Valentin (1988) reported a fivefold increase of infiltration in the presence of the earthworm and termite as compared with soils where they were absent.

\section{Regulation of Soil Organic Matter Dynamics}

In soils of the humid tropics, endogeic earthworm activities significantly affect SOM dynamics both in the short term (acceleration of nutrient release) and long term (physical protection of SOM in casts). Such effects are a direct consequence of the mutualistic relationship that links these worms to the soil microflora in a common exploitation of SOM resources (Barois \& Lavelle, 1986; Martin et al., 1987). These effects are generally significant 


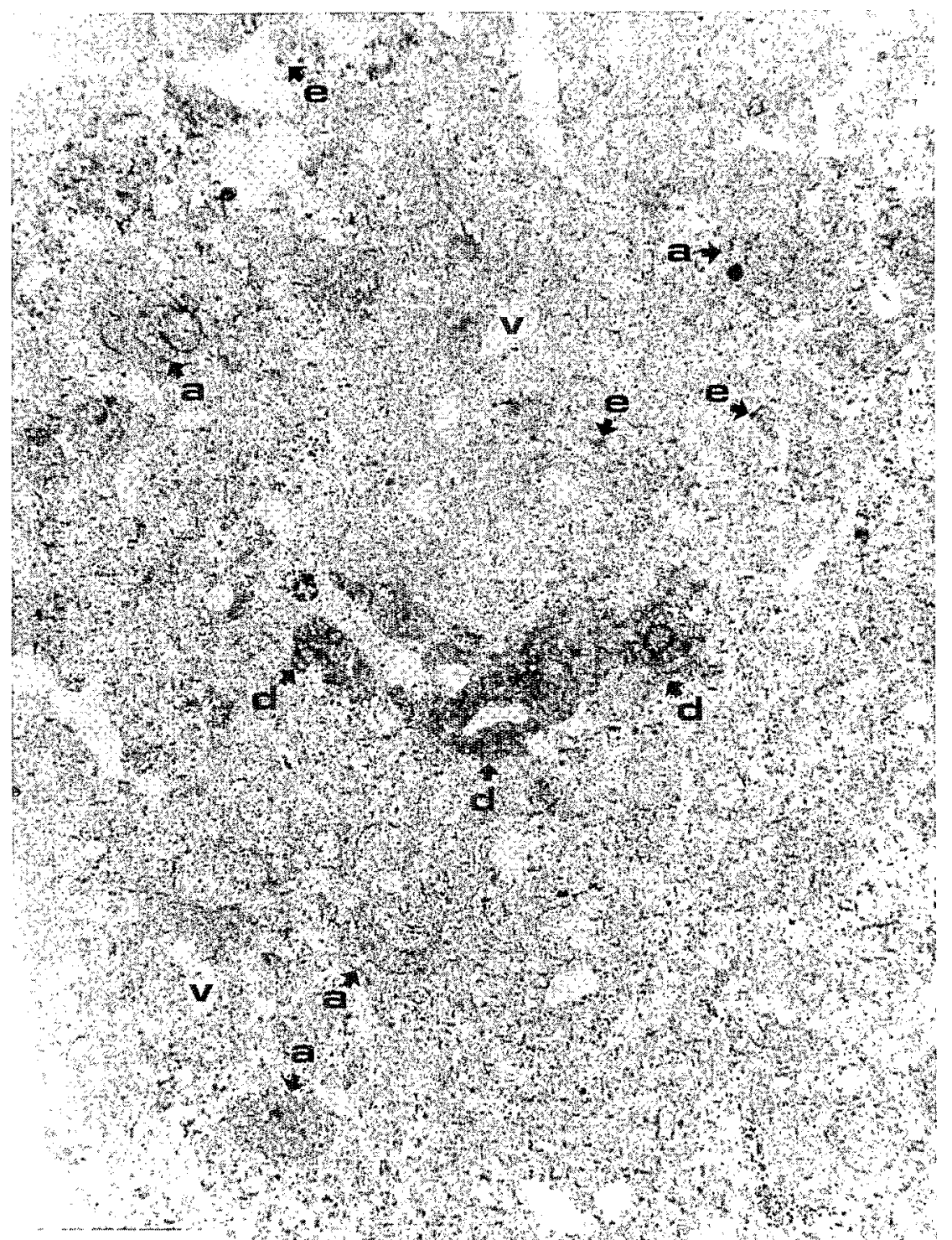

$1 \mathrm{~cm}$

Fig. 9-6. Thin section of soil of a shrub savanna at Lamto (Ivory Coast). The large earthworm fills its galleries with large impacted casts (a). These casts have a thin external layer rich in clay minerals and organic matter; the innerpart has a higher porosity. Small filiform Eudrillidae produce compact casts with a high organic content (e). Large casts with a fine texture (d) are also apparent. Voids (v) are numerous, due to compaction of soil in casts and deposition of part of the ingested soil as surface casts. 


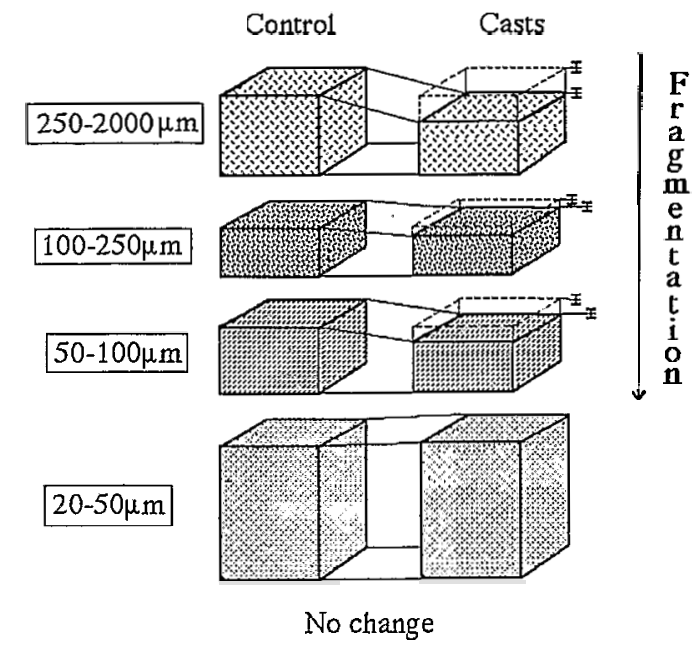

\begin{tabular}{lll}
\hline Total (mgC.g-1 soil) & $11.00 \quad 10.60$
\end{tabular}

Assimilation 2-6\%

Fig. 9-7. Changes in abundance and particle size structure of soil organic matter of a savanna soil (Lamto, Ivory Coast) after digestion by the endogeic earthworm Millsonia anomala (Martin, 1989).

at the scale of the whole soil profile as a consequence of high ingestion rates. At Lamto, the $1000 \mathrm{Mg} \mathrm{ha}^{-1}$ ingested by the endogeic earthworm, on average may contain $15 \mathrm{Mg}$ SOM (i.e., one-third of the total SOM accumulated in a grass savanna soil), and $60 \%$ of the SOM in the 10 upper $\mathrm{cm}$ where earthworm activity is concentrated (Lavelle, 1978). Other estimates made in Mexican (C. Fragoso, 1990, unpublished data) and Costa Rican pastures (Fraile, 1989) give ingestion figures of about 350 to $500 \mathrm{Mg} \mathrm{ha}^{-1}$ and 17.5 to $25 \mathrm{Mg}$ of SOM.

\section{Short-Term Effects}

Assimilation of Soil Organic Matter. The assimilation of SOM by the earthworm ranges from 2 to $9 \%$ in the African species Millsonia anomala to a maximum of $18 \%$ in the pantropical Pontoscolex corethrurus (Lavelle, 1978; Martin et al., 1990; Barois et al., 1987).

By using natural ${ }^{13} \mathrm{C}$ labelling of SOM particle-size fractions, it has been shown that $M$. anomala digests equally the coarsest organic fractions (assumed to be young and relatively assimilable) and the finest ones (assumed to be old and resistant) (Martin et al., 1991b).

During digestion, a clear change occurs in the distribution of SOM among the particle-size fractions: in the casts of the African endogeic $M$. anomala, the relative abundance of organic matter associated with coarse fractions decreased sharply ( $-25 \%$ in the $250-2000 \mu$ m fraction) while that 


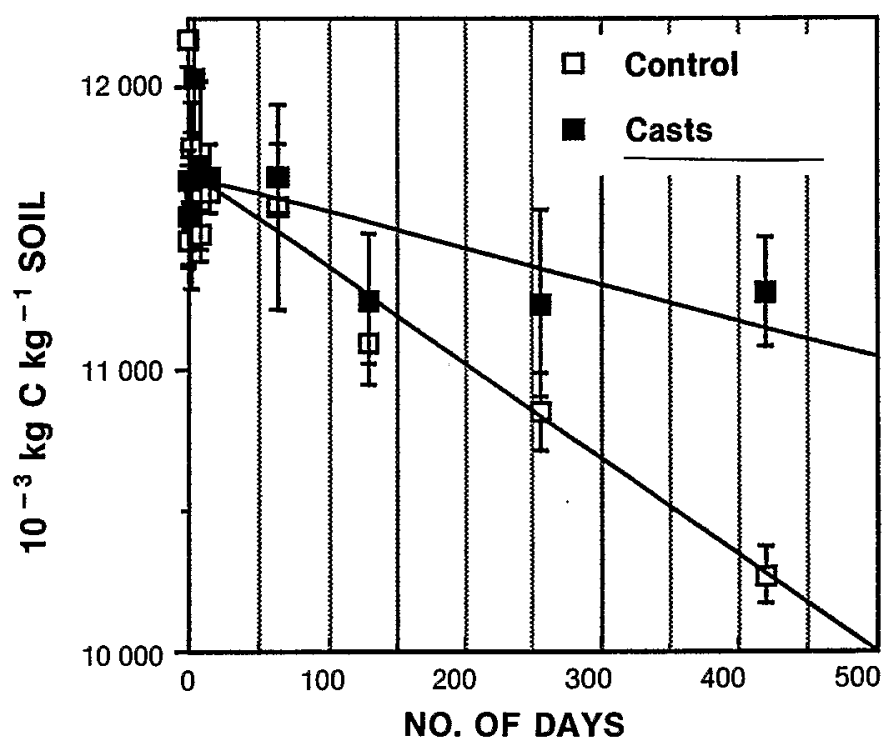

Fig. 9-8. Variation in total $\mathrm{C}$ content of casts of the endogeic earthworm Millsonia anomala and a $2 \mathrm{~mm}$-sieved control soil in long-term laboratory incubations (savannah sandy alfisol, field capacity, $27^{\circ} \mathrm{C}$ ).

in the finer fractions tended to increase. This difference mainly resulted from comminution (fragmentation without digestion) of the largest fragments, since all fractions were assimilated at the same rate (Fig. 9-8).

Release of nutrients. Transit of SOM through the earthworm gut results in the release of significant amounts of assimilable nutrients. Fresh casts of $P$. corenthrurus fed on the soil of the upper $10 \mathrm{~cm}$ of a 15 -yr-old secondary forest at Yurimaguas (Peru) contained up to $13310^{-3} \mathrm{~kg} \mathrm{~kg}^{-1}$ mineral $\mathrm{N}$ divided into $111 \mathrm{mg}$ ammonium $\left(\mathrm{NH}_{4}\right)$ (i.e., 18.2 times the value in uningested soil) and $22.4 \mathrm{mg}$ nitrate $\left(\mathrm{NO}_{3}\right)$ (1.12 times the control) (Lavelle, Melendez, Schaefer \& Pashanasi, In preparation). Comparable measurements made on the casts of $M$. anomala fed on a savanna soil at Lamto (Ivory Coast) only contained $24.510^{-3} \mathrm{~kg} \mathrm{~kg}^{-1} \mathrm{NH}_{4}$ and only $0.510^{-3} \mathrm{~kg} \mathrm{~kg}^{-1} \mathrm{NO}_{3}(\mathrm{P}$. Lavelle and S. Martin, 1990, unpublished data). In this case, it represented a net mineralization rate of $3 \%$ and an overall annual release by natural field populations of 13 to $18 \mathrm{~kg} \mathrm{ha}^{-1}$.

Ammonium concentration rapidly decreased in the casts. In the savanna soil of Lamto, nitrification was negligible and $\mathrm{NH}_{4}$ concentration decreased below control levels after $8 \mathrm{~d}$. In a forest soil of Peruvian Amazonia, $\mathrm{NH}_{4}$ concentration in casts of $P$. corethrurus decreased much more slowly with time. After $16 \mathrm{~d}, \mathrm{NH}_{4}$ concentration in casts was still 2.5 times the control value. Part of it had undergone nitrification and the resulting $\mathrm{NO}_{3}$ concentration was $71.1 \mathrm{mg} \mathrm{kg}{ }^{-1}$, that is, 3.55 times the initial control value. This decrease of mineral $\mathrm{N}$ in casts was probably due to microbial reorganization since no leaching was permitted to occur, no plants were avail- 
Table 9-1. Available forms of $\mathbf{P}$ (water-extractable and exchangeable) in casts of $P$. corethrurus of different ages from soils with a low (Lamto) and high (Laguna Verde) $P$ retention capacity (Lopez-Hernandez, Lavelle, and Fardeau, 1991, unpublished data) (means accompanied by the same letter are not significantly different; $P<0.05$ ).

\begin{tabular}{lcr}
\hline & Water extractable P & \multicolumn{1}{c}{ Exchangeable P } \\
\cline { 2 - 3 } & & \\
& & \\
& & \\
Lamto (sandy alfisol) & $0.060+1-0.005 \mathrm{a}$ & $2.00+/-0.11 \mathrm{a}$ \\
Control soil & $0.158+1-0.005 \mathrm{~b}$ & $6.00+1-1.78 \mathrm{~b}$ \\
Casts 12 h & $0.499+1-0.10 \mathrm{c}$ & $15.89+1-1.78 \mathrm{c}$ \\
Casts 96 h & & \\
Laguna Verde (vertisol) & 0.026 & $15.00+/-0.78 \mathrm{~b}$ \\
Control soil & 0.021 & $10.11+/-1.78 \mathrm{a}$ \\
Casts 12 h & 0.053 & $43.33+1-1.11 \mathrm{c}$ \\
Casts 24 h & 0.032 & $11.44+1-1.11 \mathrm{a}$ \\
Casts 96 h & &
\end{tabular}

able to act as a sink and denitrification would have been unlikely (P. Lavelle et al., 1990, unpublished data).

Among other nutrients critical for plant growth, $\mathrm{P}$ availability seems to be affected by endogeic earthworm activities. In casts of $P$. corethrurus, exchangeable and water extractable inorganic $P$ increase with time. Maximum values of, respectively, two to eight times and three to eight times the control have been measured after 1 to $4 \mathrm{~d}$ (D. Lopez-Hernandez et al., 1990, unpublished data) (Table 9-1).

\section{Long-term Effects}

It seems probable that in soils with high endogeic populations, little, if any, resistant organic matter would accumulate in the upper $20 \mathrm{~cm}$ of the profile where earthworm activity concentrates since no organic pool seems resistant to decomposition in their gut. In soils where such an endogeic drilosphere effect predominates, the turnover of SOM is thus expected to be extremely rapid. This has been observed in the Lamto savanna where endogeic earthworm populations are abundant and active: a natural ${ }^{13} \mathrm{C}$ labelling of SOM was effected due to a rapid afforestation of the savanna after protection from fire. The half-life time of SOM was estimated at, respectively, about 8 and $19 \mathrm{yr}$ for the coarse 50 to $2000 \mu \mathrm{m}$ "labile" and 2 to $50 \mathrm{yr}$ "resistant" particle-size fractions (Martin et al., 1990). Despite the clear acceleration of turnover due to the mutualistic digestive system of the earthworm (in association with the free-living soil bacteria), a system of SOM protection in casts, of $M$. anomala subsequent further to digestion, has been described (Martin, 1989). Mineralization of SOM decreases sharply with time in the casts and stabilizes at a minimum after a few days. As a result, SOM content of casts soon overtook values measured in a control noningested 2-mm sieved soil, incubated under similar conditions (Fig. 9-8) and after 1 $\mathrm{yr}$, the total amount of SOM mineralized in casts was $40 \%$ less than in the control. 


\section{Earthworm Activities and Plant Growth}

The effect of the endogeic earthworm on SOM dynamics is thus that of a "release-and-block" system with phases of extremely intensive mineralization, during digestion, and further inhibition of mineralization, probably due to physical protection of SOM in the compact structure of the casts. One peculiarity of this system is that it may well function in synchrony with plant demand for nutrients: in a microcosm experiment associating the endogeic worm ( $M$. anomala) and a plant (Panicum maximum Jacq.) ${ }^{15} \mathrm{~N}$ labelled worms rapidly eliminated their ${ }^{15} \mathrm{~N}$ as $\mathrm{NH}_{4}$ in their casts and part of this ${ }^{15} \mathrm{~N}$ was subsequently transferred to the plant (Spain et al., 1991, in press).

In pot experiments, improvements in plant growth in the presence of the endogeic earthworm have been reported. In the above-mentioned experiment, the growth of $P$. maximum Jacq. increased with increasing earthworm biomass up to a maximum value of 2.8 times the control after $70 \mathrm{~d}$. Nitrogen concentration was increased by, respectively, 29 to $116 \%$ in leaves and 88 to $260 \%$ in roots. Phosphorus content was increased in roots (+58-152\%) while no significant change was observed in the leaves.

At Yurimaguas (Peruvian Amazonia), the effect of $P$. corethrurus on the growth of seedlings of three different tree species was assessed during a 120-d growth period (Pashanasi et al., 1991, unpublished data). Bixa orellana grew three times higher in the presence of earthworms than in their absence; Eugenia stipitata grew 1.3 to 1.7 times higher while no significant effect was observed with Bactris gasipaes. The different responses of tree seedlings were probably due to variation in the abundances and distributions of the root systems that would allow a much better use of nutrients released by the earthworm in the case of $B$. orellana (dense, deep-rooting system) than in $B$. gasipaes (low density of coarse superficial roots). Dramatic effects on $\mathrm{N}$ mineralization and microbial biomass were observed.

Recent studies (Redell \& Spain, in preparation) show that endogeic, and other earthworms, strongly influence the distribution of mycorrhizal propagules. This particularly applies to the spores of vesicular-arbuscular mycorrhizae that are concentrated in their casts, probably through preferential feeding in the rhizosphere (Spain et al., 1990b). Part of the growth simulation previously considered may thus result from an earlier and greater level of mycorrhizal infection of the host plant. In addition, casts of these earthworms possess higher levels of some plant-available nutrient elements and their placement in areas of low soil strength make them preferential root growth and infection pathways.

\section{TERMITE EFFECTS: THE TERMITOSPHERE SYSTEM}

The termite is not a diverse group. Taxonomically, they are divided into the "higher" termites of the family Termitidae while the "lower" termites comprise the remaining five families. Grasse (1986) estimated that more than 
2000 species of termites are currently known, the majority of which are found in the tropics.

Where common, termites play important ecological roles. Apart from the few species that attack living plants, almost all termites feed on dead organic matter, breaking it down in a complete way and sequestering SOM and plant nutrients for considerable periods in their nests, mounds, galleries, and other structures. Erosion of aboveground structures constantly returns these nutrients to the soil surface and underground structures also decay allowing their contained nutrient elements to be again taken up by plants. This leads to a nutrient patchiness in the landscape that preserves the ecological diversity. In many infertile environments, the only place where plants requiring a high nutrient status may grow is on or adjacent to termitaria. The extensive underground gallery systems created, greatly improve soil aeration and water movement. Termites may also help to restart biological nutrient cycling in degraded ecosystems through the same mechanism.

Termite colonies are divided into several castes permitting a division of labor. Reproduction is normally confined to a single pair of individuals, the king and the queen. Workers forage for food and build the mounds while highly specialized soldiers defend the colonies against predators and the inroads of termites from surrounding colonies. Termite colonies reproduce by periodically releasing reproductives that mate and then may establish new colonies separate from those within which they were reared. However, new colonies may also establish from secondary reproductives where part of the original colony becomes isolated from its parent, or the original queen dies.

Termites have their greatest influence in the ecosystems of the tropics and subtropics, and it is there that they also have their greatest effects on soils. The effects of termites on soil morphology and processes are significant at scales ranging from the catena (e.g., Wielemaker, 1984), to the microaggregate (e.g., Garnier-Sillam et al., 1985) and even the clay mineral layer (Boyer, 1982).

\section{Termite and Soil Textural Relationships}

Termite distribution and activity are both affected by, and affect soil texture. The mound-building termite is largely excluded from vertisols on the savanna lands of northern Australia, and elsewhere, due to the instability induced by the expansive smectitic clays present (e.g., Holt \& Coventry, 1982). A lack of clay may also limit the mound-building termite; the woodfeeding species Coptotermes acinaciformis is excluded from deep sandy soils in Western Australia, apparently for this reason (Lee \& Wood, 1971).

The termite substantially affects surface processes by transporting soil from various depths in the profile to the surface, where it is built into epigeal mounds and other structures. Surface structures erode continuously leading to a redistribution of soil materials in the landscape. Because termites generally select the smaller particles from within the profile, materials brought to the surface are commonly finer in texture and may have a different clay mineral composition than those of the original surface (Boyer, 1982). Thus, 
abstraction of finer particles and their surface deposition lead to the gradual build up of a stone-free surface soil (e.g., Williams, 1968). Net annual increments in the thickness of such soils have been estimated to range from 0.01 to $0.10 \mathrm{~mm} \mathrm{yr}^{-1}$ (Lee \& Wood, 1971). This is an important pedological and ecological process in the large areas of the tropics and subtropics where the termite fauna is dominated by species that form epigeal mounds. Beneath the surface, changes in texture, porosity, and the distribution of organic and mineral matter are some of the many consequences of their presence.

\section{Effects of Termite on Soil Structure}

The termite has profound effects on soil structure through their moundbuilding activities, aggregate formation, and the creation of systems of subterranean galleries and storage chambers. Although the so-called subterranean termite does not build mounds, they may have considerable influence on soil structure. Nonetheless, epigeal mounds are highly visible structures of substantial importance in terms of pedogenesis and plant growth, both directly and in terms of their erosion products. While a range of termitederived structures are known from mounds and gallery walls, less is known of their contribution to soil aggregation away from the immediate environs of the mounds or of the role of subterranean termites in this regard. Termite galleries act as a network of horizontal and vertical macropores influencing bulk density, aeration, and water infiltration and permitting movement of materials both upwards and downwards within the soil (e.g., Wielemaker, 1984). Movement of these soil materials through the galleries is mediated both by the activities of the termites and physical processes.

\section{Mounds}

Mounds may be abundant; Aloni and Soyer (1987) report populations of more than 5000 mounds $\mathrm{ha}^{-1}$ from Zaire, principally of the humivorous termite Cubitermes. The aboveground parts of termite mounds may weigh some hundreds of tons per hectare and occupy considerable proportions of the soil surface, depending on their type. In tropical Australia, mounds may number up to $1100 \mathrm{ha}^{-1}$ representing approximately $62 \mathrm{tha}^{-1}$ of soil and covering $1.7 \%$ of the sampled area (Wood \& Lee, 1971). However, the median mass for the 58 sites recorded in Spain et al. (1983) is only $20 \mathrm{t} \mathrm{ha}^{-1}$ (interquartile range 15-25) and the median area covered by their bases is only $0.8 \%$ of the sampled areas (interquartile range 0.5-1.1). Similar estimates from Africa range up to $10 \%$ of the area sampled. Although Meyer (1960) recorded the bases of mounds at one site as covering an exceptional $33 \%$ of the soil surface, representing an estimated dry mass of $2400 \mathrm{tha}^{-1}$. Where populations of mounds are high, they are frequently overdispersed (Spain et al., 1986) suggesting that termite populations may tend to fully use the normal organic resources available to them in the landscape. This is reinforced by the denudation and dietary shifts that occur during drought years (Lepage, 1981). 
The epigeal mounds built by the termite are usually fine-textured, cemented, hard and massive structures that shed almost all the water that impinges on them. Through the energy of rainfall impact and runoff, a steady erosion of mound surfaces occurs even where they still contain healthy populations (Bonell et al., 1986). It is possible that this may limit the geographic distribution of some termite species whose mounds lack specific adaptations for water shedding. There must be a substantial energy cost to termite colonies attributable to erosional losses during mound building and repair; the soil materials recently added to epigeal termitaria are particularly susceptible to erosion, at least until hardened by curing or internal repacking processes.

After the colony has died, or the mound has been broken up, the resistant mound materials erode slowly and may continue to modify local drainage patterns for considerable periods. Where mounds are common, an area equivalent to the entire soil surface will be covered by their bases over quite short geological times. For example, the median area of the bases of the mounds recorded from the northern Australian sites given above is $0.8 \%$ of the land surface area (Spain et al., 1983). Given that this figure remains constant over time, an area equivalent to the whole surface will have been covered by the bases of termite mounds in approximately 125 generations of mounds. If the turnover time of the mound materials is assumed to be of the order of 30 to $50 \mathrm{yr}$, this represents a period of 3730 to $6250 \mathrm{yr}$, a short period in terms of soil formation.

Simple calculations of this type patently underestimate the effect of termite mounds on the soil. Many incipient colonies build small mounds but fail through the effects of predation, competition, or other factors. In addition, the soil materials brought to the surface to form runways and cover food supplies has only occasionally been quantified. The few data available suggest that this may be in the order of $1 \mathrm{Mg} \mathrm{ha}^{-1} \mathrm{yr}^{-1}$ (see, e.g., Bagine, 1984).

The turnover times of mound soil materials are poorly known, but are substantially longer than the life spans of the colonies that construct the mounds. Individual mounds of Nasutitermes triodiae in northern Australia are known to have existed for approximately $100 \mathrm{yr}$ (Watson, 1972) and medium-sized mounds from a range of species and localities are recorded as having existed for 30 to $115 \mathrm{yr}$ (Grassé, 1984). For the soil materials of a population of small mounds (principally humivores of the genus Cubitermes) from Zaire, Aloni and Soyer (1987) estimated a turnover time of approximately $10 \mathrm{yr}$. In addition to erosion by raindrop impact and runoff water, mounds are also subject to damage by termitophilous vertebrates and cattle.

\section{Aggregate Formation}

Sleeman and Brewer (1972) have described a wide range of structures from termite mounds. More recently, Kooyman and Onck (1987) also used micromorphological concepts in categorizing termite-derived structures in 
soils distant from mounds. Apart from fragments of mound materials, storage structures and gallery walls, few aggregates have been directly attributed to termite activity. Garnier-Sillam et al. (1985), however, have recently described organo-mineral microaggregate structures from the feces of four species of termites of different ecological strategies and Eschenbrenner (1986) has remarked on the similarity of aggregates in termite-inhabited soils to those from the mounds. It is apparent that much progress remains to be made in this area of study.

The effects of termites on soil structure depend on the ecological strategies of the local termite population. Higher percentages of water-stable aggregates have been recorded by several authors from termite-affected soils. This is illustrated by the work of Garnier-Sillam et al. (1988) who report contrasting effects on soil structure by two sympatric species of termites from the Congo. In the situation studied, a humivorous termite, Thoracotermes macrothorax builds mounds and other structures with a high organic matter content and a relatively low level of clay enrichment. In contrast, the mounds of the fungus-cultivating species Macrotermes mulleri and their associated surface soils, were highly clay-enriched and had low organic matter contents. Both the mound wall materials of $M$. mulleri and the soil from the A1 horizon associated with them were markedly less permeable to water and less stable than the control surface soils while with $T$. macrothorax, the opposite pertained. These authors noted a strong correlation between the organic matter content of the soil and stability. A surface-sealing effect was also associated with dispersion of the clay-enriched materials from the mounds of $M$. mulleri. This has been noted elsewhere, particularly in conjunction with degrading termitaria.

\section{Galleries}

The importance of termite galleries in influencing the physical properties of soils has been recognized for some time in locations where populations are large (Lee \& Wood, 1971), although few quantitative data are available. In an experimental study in a desert ecosystem, Elkins et al. (1986) reported higher bulk densities, lower infiltration rates, and higher bedloads in runoff waters from areas where subterranean termites had been eliminated.

It is apparent from the studies conducted so far that the nature, depth distribution, and extent of such galleries varies markedly with the species involved. For example, those of the humivorous termites are usually more superficial than those of the Macrotermitinae. Termite galleries vary in shape from circular to narrowly elliptical, and in size, from $<1 \mathrm{~mm}$ to more than $20 \mathrm{~mm}$ in cross section (Grassé, 1984). Gallery lengths of up to $7.5 \mathrm{~km} \mathrm{ha}^{-1}$ (Darlington, 1982) have been recorded from soils associated with the mounds of Macrotermes michaelseni although Wood (1988) felt that this figure could perhaps have been doubled to account for those of the subterranean termite species present. In addition, the equivalent of 90000 storage chambers ha ${ }^{-1}$ were also present in the study area. Assuming that these structures were largely confined to the top $20 \mathrm{~cm}$ of the soil and applying Wood's estimate, it may 
be calculated that termite galleries and related structures occupied approximately $0.4 \%$ of the soil volume of this zone.

\section{Termites and Soil Organic Matter}

As previously stated, termites feed basically on cellulosic materials. However, the feeding habits of soil-dwelling termites cannot be classified in the same way as those of the earthworm or other soil animals. This results from the fact that while these termites make their nests and live in soil or mounds, most species derive their nutrition from above or close to the soil surface. In addition, termites do not limit their activities to any one horizon. Most species are thus surface or near-surface feeding saprovores; some species harvest the dead foliage of grasses, seeds, the feces of higher animals and other materials from the soil surface. A wide range of species attack dead wood and perform a useful role in recycling these materials in nature, although they frequently damage human's wooden constructions. The species of one further group, the humivores, feed on organic matter within the soil. Several species also feed on living plants both above and below ground and some are serious pests of crops and other plants.

The ecological impact of termite feeding may be large. Lepage (1972) reports that termites in low-lying parts of sahelian grasslands of Sénégal may consume up to $49 \%$ of annual herbage production, although the overall figure for the area was $5.4 \%$. In further studies of semiarid pastures in Kenya, Lepage (1981) estimated that termites and grazing mammals had similar impacts both consuming approximately $1 \mathrm{Mg} \mathrm{ha}^{-1} \mathrm{yr}^{-1}$. Lee and Wood (1971) have reported that Nasutitermes exitiosus consumed $16 \%$ of the total estimated fall of leaves and sticks or $4.9 \%$ of the total annual litter fall in an Australian dry sclerophyll forest. Similar figures for Malaysian rainforests range from $1 \%$ for a site prone to flooding to $16 \%$ for a relatively dry forest whose termite fauna was dominated by Macrotermitinae (Collins, 1983).

In terms of the impact of termite grazing on soil, Lepage (1981) reported that African Macrotermes spp. may, in drought years, shift their diet from normal litter-feeding habits to feeding on standing herbaceous vegetation and, with increasing severity of drought, to feeding on roots. This destabilizes the soil surface and renders it readily susceptible to erosion and degradation. In sites where the Macrotermitinae are the dominant termites, it appears that a higher proportion of annual litter fall may be recycled through termites and this has been ascribed to the high efficiency of the symbiotic relationship with species of the fungus genus Termitomyces, described below.

Under some circumstances, a relationship between termite presence and soil organic matter concentrations has been demonstrated. This was shown by Parker et al. (1982) who found increased organic matter in desert soils following removal of the termites present. Similarly, the absence of fire and an effective termite fauna from the vertisol studied by Moore et al. (1967) in subtropical Australia, were considered to be the causes of the large-standing crop biomass of aboveground dead organic matter. Moore et al. (1967) estimated that there were $75 \mathrm{Mg} \mathrm{ha}^{-1}$ of litter together with $58 \mathrm{Mg} \mathrm{ha}^{-1}$ of 
standing dead material on the site in addition to elevated levels of soil organic matter and $\mathrm{N}$.

\section{Termite Digestive Processes}

A feature of many termite foodstuffs is their relative recalcitrance to breakdown; most are low in $\mathrm{N}$ and materials normally considered as readily assimilable. Nonetheless, assimilation rates in the termites are high and published values range between 54 and $93 \%$ of the food eaten (Wood, 1978). Termite foodstuffs are normally rich in lignin and other resistant plant compounds. This has led to the apparently universal associations with microorganisms which, with their wider spectrum of enzymatic capacities, contribute much to the breakdown of the resistant material eventually assimilated.

Digestive mechanisms differ between the more highly evolved Termitidae and the remaining or lower termite families. In the lower termites, digestion of resistant materials appears to be carried out largely by the obligately anaerobic protozoans that inhabit a specialized region of the hind gut, while in the higher termites, these protozoans are absent or ineffective. In addition, in the lower termites, a wide range of bacteria play diverse but, as yet ill-defined nutritional roles. In the higher termite, the animal's own enzymes are perhaps more effective in carbohydrate breakdown. Although, there is also a prominant fermentation in the hind gut with acetic acid being the major end product of cellulose breakdown in all termites (Breznak, 1984). In addition, acquired enzymes play an important role in cellulose digestion in at least some Macrotermitinae (Martin, 1984) while members of this subfamily derive much of their nutrition through the degradational activities of the basidiomycete fungus Termitomyces cultivated in their nests (Thomas, 1987a,b).

Lignin appears to be degraded by termites although the mechanisms are as yet unclear, since the known methods of degradation are aerobic (Kirk \& Farrell, 1987). Butler and Buckerfield (1979) and Cookson (1987) demonstrated the evolution of labelled $\mathrm{CO}_{2}$ from live termites that had been fed lignin labelled with ${ }^{14} \mathrm{C}$ in various parts of its structure. Cookson (1987) found that both higher and lower termites had some capacity to degrade lignins although their capacities to do so differed between lignins from different sources.

Nitrogen-fixing organisms have been found in the gut of termites and efficient $\mathrm{N}$ conserving mechanisms are known from the Isoptera (Breznak, 1984). These include behavioral traits such as cannibalism, necrophily, and the ability of at least some termites to reabsorb uric acid from the hind gut.

\section{Organic Matter in Termite-derived Structures}

Carbon levels in epigeal termite structures are normally higher than those of the soils from which they are formed, because of the salivary or fecal materials that are frequently used as adhesives. One such salivary adhesive from the mound wall of the wood-feeding species Coptotermes acinaciformis has been identified as a glycoprotein (Gillman et al., 1972). In structures 
formed mainly from soil materials, the degree of organic matter enrichment depends primarily on whether feces are included. Thus, the $C$ content of the mounds of the Macrotermitinae is lower than that of the humivores because the former do not include feces in the mounds. The $\mathrm{C} / \mathrm{N}$ ratio is higher in many termite-derived materials than in the surrounding surface soils although the organic matter of the humivorous species is an obvious exception to this. Lee and Wood (1971) showed that this ratio was higher in mound materials from wood-feeding species than in grass-feeding species.

The centers of the mounds of certain wood- and grass-feeding termites consist of carton, a mixture of excreta, some inorganic materials and fragments of undigested, comminuted plant material. Organic matter in carton is high and that in the mounds of Coptotermes acinaciformis, a wood-feeding termite from northern Australia, ranged from 83 to $93 \%$ loss-on-ignition (Lee \& Wood, 1971).

Soils beneath and adjacent to termitaria are also modified, often by physical processes such as the erosion of materials from mounds. In tropical Australia, the mounds of litter and grass-feeding termites (Amitermes spp.) are surrounded by an erosional pediment that has $\mathrm{C}$ levels similar to the mound materials, or intermediate between these and soils further from the mounds. While plants only occasionally grow on the mound surfaces because of their hardness and low water contents, the increased fertility of the pediments is evidenced in the field by the dominance of the annual grasses and forbs. These contrast with the perennial grasses and sedges found on the less-fertile soils further from the mounds (Arshad, 1982; Spain \& McIvor, 1988). The enhanced glasshouse growth of test plants on materials from these mounds (Okello-Oloya \& Spain, 1986) and from soils beneath and adjacent to the mounds (Spain \& Okello-Oloya, 1985) further evidences their relatively higher fertility than surface soils distant from the mounds.

There have been few detailed studies of the nature of the organic matter of termite mounds. Lee and Wood (1971) presented information on the levels of organic matter and selected organic and inorganic components in mound materials and the carton of several Australian wood and grass-feeding termites. Other studies have concentrated on the mounds of the Macrotermitidae. Arshad et al. (1988) studied the organic matter from the mounds of two African Macrotermitinae (Macrotermes michaelseni and M. herus). Generally, humic acids from soils were shown to have higher molecular weights and less aromatic materials than those from the mounds. In moving from the outer wall of the mounds of the Macrotermes spp. to the nursery to the royal chamber, the concentration of $\mathrm{CO}_{2} \mathrm{H}$ groups increased and that of the carbohydrate and other O-substituted carbon decreased. Some intersite variation in the composition of the organic matter of the Macrotermes mounds was also noted. Carton from the Australian mounds studied was shown to be high in lignin and humic acids, with higher lignin, total carbohydrate and $\mathrm{N}$ concentrations and $\mathrm{C} / \mathrm{N}$ ratios in the wood-feeding species than in the grass-feeding species.

The fungal comb of $M$. michaelseni has been studied by Arshad and Schnitzer (1987) and Arshad et al. (1988). These authors found that its ash 
content was approximately $14 \%$. The approximate composition of the organic matter was $40 \%$ carbohydrate (all of which occur as polysaccharides which on hydrolysis were shown to be dominated by glucose), $10 \%$ protineaceous material (all as peptides or longer-chain structures). Appreciable aliphatic and aromatic plus phenolic materials were also noted. Using fractionation techniques commonly used for soil materials, the base-insoluble humin ( $40 \%$ of organic matter) was found to be mostly carbohydrate while the humic acid $(40 \%)$ and fulvic acid $(20 \%)$ components contained most of the aromatic material.

The $\mathrm{d}^{13} \mathrm{C}$ values (proportional distribution of the ${ }^{13} \mathrm{C}$ and ${ }^{12} \mathrm{C}$ carbon isotopes) of organic matter in the soil materials from termitaria in the savannas of Lamto (Côte d'Ivoire) are up to $5.5 \mathrm{~d}^{13} \mathrm{C}$ units more negative than those of the surrounding surface soil (A.V. Spain and M. Lepage, 1988, unpublished data). The more negative values of the mound materials may be due to those of the lignin-enriched humified organic matter of the termite feces. Alternatively, some of the organic matter of the mounds may be derived from the woody $\left(C_{3}\right)$ vegetation that grows on the surface of the mounds in addition to the $\left(\mathrm{C}_{4}\right)$ grasses.

\section{DISCUSSION}

The two major myths addressed in the introduction have been shown to be demonstrably inaccurate. Both the earthworm and termite clearly influence tropical ecosystems, both natural and man-modified. Their distribution patterns are closely related to rainfall, vegetation, edaphic, and biogeographic factors. Earthworms are confined to areas with an annual rainfall $>800 \mathrm{~mm}$ on the average. Termites exist in much drier climatic conditions. They become predominant in semiarid and arid environments.

The second myth that assumes that earthworm abundance might be a consequence rather than the cause of soil fertility is refuted through an understanding of the processes relating production processes to soil structure and the maintenance of fertility.

Our present knowledge of the role of soil macroinvertebrates in the humid tropics suggests that they may be efficient agents in the maintenance of soil fertility. Apart from the termite and earthworm, other soil faunal components are also important. For example, arthropods of the litter system that accelerate the transformation and incorporation of litter into the soil and the microfauna that represents an intermediate level of regulation between macro- and microorganisms (i.e., bacteria and fungi) are important. At the higher trophic levels, the ant exerts considerable predation pressure on the soil meso- and macrofauna and are sometimes important pedogenetic agents (Holldobler \& Wilson, 1990).

It has been observed several times that certain agricultural practices are detrimental to soil fauna communities of the natural ecosystem (Critchley et al., 1979; Lavelle \& Pashanasi, 1989). Cultures of maize leave little of the original fauna and no adaptable alternative fauna is generally present. Sys- 
tems associating trees (e.g., peach-palm Bactris gasipaes or Hevea) with a plant cover of legumes may conserve a significant part of the original fauna whereas pastures may occasionally be colonized by peregrine endogeic earthworm species (like e.g., Pontoscolex corethrurus) that can build up large populations with biomasses of up to 1 to $4 \mathrm{Mg}$ fresh wt. ha ${ }^{-1}$.

These observations are still too scarce. The possibility to maintain or improve soil fertility by manipulating the activities of soil fauna needs to be explored. This field of research, however, is regarded as having considerable potential (see e.g., Swift, 1984; Lavelle et al., 1989). Preliminary shortterm experiments (on short scales of time and space) have demonstrated that considerable improvements in plant production and the maintenance of fertility may be gained through a proper management of this resource.

A better knowledge is required of the biology of a wide range of species adaptable to the relatively harsh ecological conditions of for example, rice fields, yucca plantations, or the environment of dry forest-like tree plantation crops (e.g., cocoa and tea). Species adaptable to such an environment may exist, but in distinct geographical areas. Earthworm species adapted to live in a maize field of the Amazon are not likely to be found in the nearby rainforest, but rather in savannas of South America and Africa whose soils have temperature and moisture regimes comparable to those of a cultivated field.

It is also important to have information on the dynamics of soil colonization by adaptable populations. Adaptable species may exist in an area, but may be impeded from colonizing because they are separated from the field by such natural barriers as a small stream or a few rows of trees.

Large-scale experiments are required to assess the effect of introducing adaptable species (or removing some, such as termite species feeding on live materia) over significant areas (about $1 \mathrm{ha}$ ) and during several successive crops, to ascertain whether the improvements observed over short periods in small experimental containers, are still maintained under conditions much closer to those of normal agricultural practice.

Finally, more attention should be paid to the often fertile soil accumulated in structures and mounds built by litter and grass-harvesting termites. The exploitation of this soil as a fertilizer, on a regular basis is practiced in a limited number of cases (Swift et al., 1989). Research should be made to evaluate the feasibility of such practices on a larger scale.

\section{REFERENCES}

Aloni, K., and J. Soyer. 1987. Cycles des matériaux de construction des termitières d'humivores en savane au Shaba méridional (Zaire). Rev. Zool. Afr. 101:329-357.

Anderson, J.M., and P. Flanagan. 1989. Biological processes regulating organic matter dynamics in tropical soils. p. 97-125. In D.C. Coleman et al. (ed.) Dynamics of soil organic matter in tropical ecosystems. NifTAL Project, Univ. of Hawaii, Honolulu.

Arshad, M.A. 1982. Influence of the termite Macrotermes michaelseni (Sjostedt) on soil fertility and vegetation in a semi-arid savannah ecosystem. Agro-Ecosystems 8:47-58.

Arshad, M.A., and M. Schnitzer. 1987. The chemistry of a termite fungus comb. Plant Soil 98:247-256. 
Arshad, M.A., M. Schnitzer, and C.M. Preston. 1988. Characterization of humic acids from termite mounds and surrounding soils, Kenya. Geoderma 422:213-225.

Ayodele, O.J. 1986. Effect of continuous maize-cropping on yield, organic carbon mineralization and phosphorus supply of savannah soils in western Nigeria. Biol. Fertil. Soil. 2:151-155.

Bagine, R.K.N. 1984. Soil translocation by termites of the genus Odontotermes (Holmgren) (Isoptera: Macrotermitinae) in an arid area of northern Kenya. Oecologia (Berlin) 64:263-266.

Barois, I. 1987. Interactions entre les Vers de terre (Oligochaeta) tropicaux géophages et la microflore pour l'exploitation de la matière organique du sol. Travaux des Chercheurs de Lamto (RCI), no. 7. ENS, Paris.

Barois, I., and P. Lavelle. 1986. Changes in respiration rate and some physico-chemical properties of a tropical soil during transit through Pontoscolex corethrurus (Glossoscolecidae, Oligochaeta). Soil Biol. Biochem. 18:539-541.

Barois, I., B. Verdier, P. Kaiser, A. Mariotti, P. Rangel, and P. Lavelle. 1987. Influence of the tropical earthworm Pontoscolex corethrurus (Glossoscolecidae, Oligochaeta) on the fixation and mineralization of nitrogen. p. 151-159. In A.M. Bonvicini and P. Omodeo (ed.) On earthworms. Mucchi Editore, Modena.

Bernhardt-Reversat, F., C. Huttel, and G. Lemée. 1979. Structure et fonctionnement des écosystemès de la forêt pluvieuse sempervirente de la Côte d'Ivoire. p. 605-625. In Ecosystèes forestiers tropicaux. Recherches sur les Ressources Naturelles XIV. UNESCO, Paris.

Billes, G.N., N. Gandais-Riollet, and P. Bottner. 1986. Effet d'une culture de graminées sur la décomposition d'une litière végétale, marquée au ${ }^{14} \mathrm{C}$ et ${ }^{15} \mathrm{~N}$, dans le sol, en conditions controlées. Acta Oecol., Oecol. Plant. 7(3):273-286.

Blanchart, E. 1990. Rôle des vers de terre dans la formation et la conservation de la structure des sols de la savane de Lamto (Côte d'Ivoire). Thèse Univ. Rennes I.

Blanchart, E., P. Lavelle, and A. Spain. 1990. Effects of biomass and size of Millsonia anomala (Oligochaeta, Acanthodrilidae) on particle aggregation in a tropical soil in presence of Panicum maximum (Gramineae). Biol. Fertil. Soils 9:5.

Bonell, M., R.J. Coventry, and J.A. Holt. 1986. Erosion of termite mounds under natural rainfall in semi-arid tropical northeast Australia. Catena 13:11-28.

Boyer, P. 1982. Quelques aspects de l'action des termites du sol sur les argiles. Clay Miner. $17: 453-462$.

Breznak, J.A. 1984. Biochemical aspects of symbiosis between termites and their intestinal microbiota. p. 173-203. In J.M. Anderson et al. (ed.) Invertebrate-microbial interactions. Cambridge Univ. Press, Cambridge.

Butler, J.H.A., and J.C. Buckerfield. 1979. Digestion of lignin by termites. Soil Biol. Biochem. 11:507-511.

Casenave, A., and C. Valentin. 1988. Les états de surface de la zone sahélienne. Leur influence sur l'infiltration. Rapport CEE-ORSTOM, ORSTOM, Bondy, France.

Chaussod, R., B. Nicolardot, G. Catroux, and C. Chrétien. 1986. Relations entre les caractéristiques physico-chimiques et microbiologiques de quelsues sols cultivés. Sci. Sol. 2:213-226.

Clarholm, M., and T. Rosswall. 1980. Biomass and turnover of bacteria in a forest soil and a peat. Soil Biol. Biochem. 12:49-57.

Coleman, D.C., C.P.P. Read, and C.V. Cole. 1983. Biological strategies of nutrient cycling in soil systems. Adv. Ecol. Res. 13:1-55.

Collins, N.M. 1983. Termite populations and their role in litter removal in Malaysian rainforests. p. 313-325. In S.L. Sutton et al. (ed.) Tropical rainforest: Ecology and management. Blackwell Sci. Publ., Oxford.

Cookson, L.J. 1987. ${ }^{14} \mathrm{C}$-lignin degradation by three Australian termite species. Wood Sci. Technol. 21:11-25.

Critchley, B.R., A.G. Cook. U. Critchley, T.J. Perfect, A. Russell-Smith, and R. Yeadon. 1979. Effects of bush clearing and soil cultivation on the invertebrate fauna of a forest soil in the humid tropics. Pedobiologia 19:425-438.

Darlington, J.P.E.C. 1982 . The underground passages and storage pits used in foraging by a nest of the termite Macrotermes michaelseni in Kajiado, Kenya. J. Zool. 198:237-247.

Elkins, N.Z., G.V. Sabol, T.J. Ward, and W.G. Whitford. 1986. The influence of subterranean termites on the hydrological characteristics of a Chihuahuan desert ecosystem. Oecologia (Berlin) 68:521-528.

Eschenbrenner, V. 1986. Contribution des termites à la microagrégation des sols. Cah. ORSTOM, sêr. Pedol. 22:397-408. 
Food and Agriculture Organization. 1981. Agriculture: Horizon 2000. Vol. 23. Développement Economique et Social. FAO, Rome.

Fragoso, C., and P. Lavelle. 1991. Earthworm communities of tropical rainforests. Soil Biol. Biochem. (in press).

Fraile, J.M. 1989. Poblaciones de Lombrices de tierra (Oligochaeta: Annelida) en una pastura de Cynodon pletostachvus (Pasto estrella) asociada con aboles de Eythina poeppigiana (Poro), una pastura asociada con arboles de Cordia alliodora (Laurel), una pastura sin arboles y vegetacion a libre crecimiento, en el CTIE, Turrialba, Costa Rica. Tesis Doctoral, Univ. de Costa Rica.

Garnier-Sillam, E., G. Villemin, F. Toutain, and J. Renoux. 1985. Formation de micro-agrégats organo-mineraux dans les feces de termites. C.R. Acad. Sci. Ser. 3 301:213-218.

Garnier-Sillam, E., F. Toutain, and J. Renoux. 1988. Comparaison de l'influence de deux termitières (humivore et champignoniste) sur la stabilité structurale des sols forestiers tropicaux. Pedobiologia 32:89-97.

Gillman, L.R., M.K. Jeffries, and G.N. Richards. 1972. Non-soil constituents of termite (Coptotermes acinaciformis) mounds. Aust. J. Biol. Sci. 25:1005-1013.

Grassé, P.P. 1984. Termitologia. Vol. 2. Masson, Paris.

Grassé, P.P. 1986. Termitologia. Vol. 3. Masson, Paris.

Herrera, R.A., C.F. Jordan, H. Klinge, and E. Medina. 1978. Amazon ecosystems: Their structure and functioning with particular emphasis on nutrients. Interciencia 3:233-240.

Holldobler, B., and E.O. Wilson. 1990. The ants. Harvard Univ. Press, Harvard.

Holt, J.A. 1987. Carbon mineralization in semi-arid northeastern Australia: The role of termites. J. Trop. Ecol. 3:255-263.

Holt, J.A., and R.J. Coventry. 1982. Occurrence of termites (Isoptera) on cracking clay soils in northeastern Queensland. J. Aust. Entomol. Soc. 21:135-136.

Jenkinson, D.S. 1966. The priming action. p. 198-207. In The use of isotopes in soil organic matter studies. J. Appl. Radiat. Isotopes, Spec. Suppl., Pergamon, Oxford.

Josens, G. 1983. The soil fauna of tropical savannas. III. The termites. p. 498-513. In F. Bourlière (ed.) Tropical savannas. Elsevier, New York.

Kirk, T.K., and R.T. Farrell. 1987. Enzymatic "combustion": The microbial degradation of lignin. Ann. Rev. Microbiol. 41:465-505.

Kollmansperger, F. 1956. Lumbricidae of humid and arid regions and their effect on soil fertility. p. 293-297. In 6th Congr. Int. Sci. Sol.

Kooyman, C., and R.F.M. Onck. 1987. Distribution of termite (Isoptera) species in southwestern Kenya in relation to land use and the morphology of their galleries. Biol. Fert. Soils 3:69-73.

Lavelle, P. 1975. Consommation annuelle de terre par une population naturelle de vers de terre (Millsonia anomala) Omodeo, Acanthodrilidae-Oligochètes) dans la savane de Lamto (Côte d'Ivoire). Rev. Ecol. Biol. Sol. 12:11-24.

Lavelle, P. 1978. Les Vers de terre des savanes de Lamto (Côte d'Ivoire): Peuplements, populations et fonctions dans l'écosystème. Publications du Laboratoire de Zoologie, Ecole Normale Supérieure, Paris.

Lavelle, P. 1983. The soil fauna of tropical savannas. I. The community structure. II. Earthworm communities. p. 477-484 and 485-497. In F. Bourlière (ed.) Tropical savannas. Elsevier, New York.

Lavelle, P. 1984. The soil system in the humid tropics. Biol. Int. 9:2-17.

Lavelle, P. 1988. Earthworm activities and the soil system. Biol. Fert. Soils 6:237-251.

Lavelle, P., I. Barois, A. Martin, Z. Zaidi, and R. Schaefer. 1989a. Management of earthworm populations in agroecosystems: A possible way to maintain soil quality? p. 109-122. In M. Clarholm and L. Bergstrơm (ed.) Ecology of arable land. Developments in Plant and Soil Sciences 39. Kluwer Academic Publ., Dordrecht, Holland.

Lavelle, P., R. Schaefer, and Z. Zaidi. 1989b. Soil ingestion and growth in Millsonia anomala, a tropical earthworm, as influenced by the quality of the organic matter ingested. Pedobiologia 33:379-388.

Lavelle, P., E. Blanchart, A. Martin, S. Martin, A.V. Spain, F. Toutain, I. Barois, and R. Schaefer. 1991. A hierarchical model for decomposition in terrestrial ecosystems: Application to soils of the humid tropics. Biotropica (in press).

Lavelle, P., and B. Kohlmann. 1984. Etude quantitative de la macrofaune du sol dans une forêt tropicale mexicaine (Bonampak, Chiapas). Pedobiologia 27:377-393.

Lavelle, P., and B. Pashanasi. 1989. Soil macrofauna and land management in Peruvian Amazonia (Yurimaguas, Loreto). Pedobiologia 33:283-291.

Lee, K.E., and T.G. Wood. 1971. Termites and soils. Academic Press, New York. 
Lepage, M. 1972. Recherches écologiques sur une savane sahélienne du Ferlo septentrional, Sénégal: données préliminaires sur l'écologie des termites. La Terre Vie 26:383-409.

Lepage, M. 1981. L'impact des populations récoltantes de Macrotermes michaelseni (Sjostedt) (Isoptera: Macrotermitinae) dans un écosystème semi-aide (Kajiado, Kenya). II. La nourriture récoltée, comparaison avec les grands herbivores. Insect. Soc. 28:309-319.

Martin, A. 1989. Effet des vers de terre tropicaux géophages sur la dynamique de la matière organique du sol dans les savanes humides. Thèse doctorat. Univ. Paris-Sud.

Martin, A., J. Cortez, I. Barois, and P. Lavelle. 1987. Les mucus intestinaux de ver de terre, moteurs de leurs interactions avec la microflore. Rev. Ecol. Biol. Sol 24:549-558.

Martin, A., A. Mariotti, J. Balesdent, P. Lavelle, and R. Vuattoux. 1990. Estimate of organic matter turnover rate in a savanna soil by ${ }^{13} \mathrm{C}$ natural abundance measurements. Soil Biol. Biochem. 22(4):517-523.

Martin, A., A. Mariotti, J. Balesdent, and P. Lavelle. 1991. Estimate of soil organic matter assimilation by a geophagous tropical earthworm based on ${ }^{13} \mathrm{C}$ natural abundance. Ecology (in press).

Martin, M.M. 1984. The role of ingested enzymes in the digestive processes of insects. p. 155-172. In J.M. Anderson et al. (ed.) Invertebrate-microbial interactions. Cambridge Univ. Press, Cambridge.

Meyer, J.A. 1960. Résultats agronomiques d'un essai de nivellement des termitières réalisé dans la cuvette centrale Congolaise. Bull. Agric. Congo Belge 51:1047-1059.

Moore, A.W., J.S. Russell, and J.E. Coldrake. 1967. Dry matter and nutrient content of a subtropical semiarid forest of Acacia harpophylla F. Muell. (Brigalow). Aust. J. Bot. 15:11-24.

Okello-Oloya, T., and A.V. Spain. 1986. Comparative growth of two pasture plants from northeastern Australia on the mound materials of grass and litter-feeding termites (Isoptera: Termitidae) and on their associated surface soils. Rev. Ecol. Biol. Sol 23:381-392.

Okello-Oloya, T., A.V. Spain, and R.D. John. 1985. Selected chemical characteristics of the mounds of two species of Amitermes (Isoptera, Termitinae) and their adjacent surface soils from northeastern Australia. Rev. Ecol. Biol. Sol 22:291-311.

Parker, L.W., H.G. Fowler, G. Ettershank, and W.G. Whitford. 1982. The effects of subterranean termite removal on desert soil nitrogen and ephemeral flora. J. Arid Environ. 5:53-59.

Pedro, G. 1983. Structuring of some basic pedological processes. Geoderma 31:289-299.

Pullan, A. 1979. Termite hills in Africa: Their characteristics and evolution. Catena 6:267-291.

Rose, C.J., and A.W. Wood. 1980. Some environmental factors affecting earthworm populations and sweet potato production in the Tari Basin, Papua, New Guinea. Agric. J. 31:1-13.

Sanchez, P.A., D.E. Bandy, and J.H. Villachica. 1983. Soil fertility dynamics after clearing a tropical rainforest in Peru. Soil Sci. Am. J. 47:1171-1178.

Sanchez, P.A., C.A. Palm, L.T. Szott, E. Cuevas, and R. Lal. 1989. Organic input management in tropical agroecosystems. p. 125-152. In D.C. Coleman et al. (ed.) Dynamics of soil organic matter in tropical ecosystems. NifTAL Project, Univ. of Hawaii, Honolulu.

Sleeman, J.R., and R. Brewer. 1972. Microstructures of some Australian termite nests. Pedobiologia 12:347-373.

Spain, A.V., P. Lavelle, and A. Mariotti. 1991. Preliminary studies of the effects of some tropical earthworms on plant growth. Soil Biol. Biochem. (in press).

Spain, A.V., and T. Okello-Oloya. 1985. Variation in the growth of two tropical pasture plants on soils associated with the termitaria of Amitermes laurensis (Isoptera: Termitinae) p. 141-145. In R.B. Chapman (ed.) Proc. 4th Australasian Conf. on Grassland Invertebrate Ecology. Caxton Press, Christchurch, NZ.

Spain, A.V., T. Okello-Oloya, and A.J. Brown. 1983. The abundances, above-ground masses and basal areas of termite mounds at six locations in tropical north-eastern Australia. Rev. Ecol. Biol. Sol. 20:547-566.

Spain, A.V., D.F. Sinclair, and P. Diggle. 1986. Spatial distribution of the mounds of harvester and forage termites (Isoptera: Termitidae) at four locations in tropical north-eastern Australia. Oecol, Gener. 7:335-352.

Spain, A.V., and J.G. McIvor. 1988. The nature of herbaceaous vegetation associated with termiteria in north-eastern Australia. J. Ecol. 76:181-191.

Spain, A.V., P.G. Saffigna, and A.W. Wood. 1990a. Tissue carbon sources for Pontoscolex corethrurus (Oligochaeta; Glossoscolecidae) in a sugarcane ecosystem. Soil Biol. Biochem. 22:703-706. 
Swaminathan, M.S. 1983. Our greatest challenge: Feeding the hungry world. p. 25-31. In G. Bixlet and L.W. Shemilt (ed.) Chemistry and the world food supplies: The new frontiers. CHEMRAWN II. Perspectives and recommendations. Int. Rice Res. Inst., Los Baños, Philippines.

Swift, M.J. 1976. Species diversity and the structure of microbial communities. p. 185-222. In J.M. Anderson and A. Macfadyen (ed.) The role of terrestrial and aquatic organisms in decomposition processes. Blackwell Sci. Publ., Oxford.

Swift, M.J. 1984. Soil biological processes and tropical soil fertility: A proposal for a collaborative programme of research. Biol. Int. Spec. Issue 5. Int. Union of Biol. Sci., Paris.

Swift, M.J., P.G.H. Frost, B.M. Campbell, J.C. Hatton, and K.B. Wilson. 1989. Nitrogen cycling in farming systems derived from savanna: Perspectives and challenges. p. 63-76. In M. Clarholm and L. Bergström (ed.) Ecology of arable land. Developments in Plant and Soil Sciences 39. Kluwer Acad. Publ., Dordrecht, Holland.

Thomas, J. 1987a. Distribution of Termitomyces Heim and other fungi in the nests and major workers of Macrotermes bellicosus (Smeatham) in Nigeria. Soil Biol. Biochem. 19:329-333.

Thomas, R.J. 1987b. Factors affecting the distribution and activity of fungi in the nests of Macrotermitinae (Isoptera). Soil Biol. Biochem. 19:343-349.

Tisdall, J.M., and J.M. Oades. 1982. Organic matter and water stable aggregates in soils. J. Soil Sci. 33:141-163.

Visser, S.A. 1985. Physiological action of humic substances on microbial cells. Soil Biol. Biochem. 17(4):457-462.

Watson, J.A.L. 1972. An old mound of the spinifex termite, Nasutitermes trioidae (Froggatt) (Isoptera: Termitidae). J. Austral. Entomol. Soc. 11:79-80.

Wielemaker, W.G. 1984. Soil formation by termites, a study in the Kisii area, Kenya. Doctoral thesis. Agric. Univ., Wageningen, Netherlands.

Williams, M.A.J. 1968. Termites and soil development near Brocks Creek, Northern Territory. Aust. J. Sci. 31:153-154.

Wood, T.G. 1978. Food and feeding habits of termites. p. 55-80. In M.V. Brian (ed.) Production ecology of ants and termites. Cambridge Univ. Press, Cambridge.

Wood, T.G. 1979. The termite (Isoptera) fauna of Malesian and other tropical rainforests. In A.G. Marshall (ed.) The abundance of animals in Malesian rainforests. Trans. 6th AberdeenHull Symp. on Malesian Ecology. Aberdeen Univ., 1978.

Wood, T.G. 1988. Termites and the soil environment. Biol. Fert. Soils 6:228-236.

Wood, T.G., and K.E. Lee. 1971. Abundance of mounds and competition among colonies of some Australian termite species. Pedobiologia 11:341-366. 